ISSN: 2302-8556

E-Jurnal Akuntansi Universitas Udayana

Vol.22.1. Januari (2018): 1-29

DOI: https://doi.org/10.24843/EJA.2018.v22.i01.p01

\title{
Pengaruh Kepemilikan Manajerial, Kebijakan Utang dan Ukuran Perusahaan Terhadap Manajemen Laba
}

\author{
Putu Teddy Arthawan ${ }^{1}$ \\ I Wayan Pradnyantha Wirasedana ${ }^{2}$
}

${ }^{1}$ Fakultas Ekonomi dan Bisnis Universitas Udayana (Unud), Bali, Indonesia
e-mail: teddyartawan581 @ gmail.com/ Telp: 087860933005
${ }^{2}$ Fakultas Ekonomi dan Bisnis Universitas Udayana (Unud), Bali, Indonesia

\begin{abstract}
ABSTRAK
Penelitian ini bertujuan untuk mengetahui bukti secara empiris pengaruh kepemilikan manajerial, kebijakan hutang dan ukuran perusahaan terhadap manajemen laba. Kepemilikan manajerial, kebijakan hutang dan ukuran perusahaan sebagai variabel independen yang diuji dalam penelitian ini sedangkan manajemen laba sebagai variabel dependen. Sampel dalam penelitian ini sebanyak 15 perusahaan jasa non keuangan yang terdaftar di Bursa Efek Indonesia tahun 2012-2015. Untuk mengukur manajemen laba dilakukan dengan menggunakan discretionary accruals yang dihitung dari model jones yang telah di modifikasi, sementara kepemilikan manajerial diukur dengan proporsi kepemilikan saham, kebijakan hutang diukur dengan debt to equity ratio (DER) dan ukuran perusahaan diukur dengan total asset.Berdasarkan hasil uji koefisien determinasi $\left(\mathrm{R}^{2}\right)$, pengaruh kepemilikan manajerial,kebijakan hutang, dan ukuran perusahaan berpengaruh 30,6 persen dan sisanya sebesar 69,4 persen dipengaruhi oleh variabel lain yang tidak dimasukan dalam penelitian.

Kata kunci: Manajemen laba, kepemilikan manajerial, kebijakan hutang, ukuran perusahaan
\end{abstract}

\begin{abstract}
This study aims to investigate empirically evidence of the effect of managerial ownership, debt policy and firm size on earnings management. Managerial ownership, debt policy and firm size as independent variables tested in this study while earnings management as a dependent variable. The sample in this study are 15 non-financial services companies listed in Indonesia Stock Exchange 2012-2015. To measure earnings management by using discretionary accruals calculated from modified jones model, while managerial ownership is measured by the proportion of stock ownership, debt policy is measured by debt to equity ratio (DER) and firm size is measured by total assets. Based on the results of determination coefficient test (R2), the effect of managerial ownership, debt policy, and firm size influence 30.6 percent and the rest of 69.4 percent influenced by other variables not included in the study.
\end{abstract}

Keywords: Profit management, managerial ownership, debt policy, company size 


\section{PENDAHULUAN}

Laporan keuangan merupakan media komunikasi yang digunakan untuk menghubungkan pihak-pihak yang berkepentingan terhadap suatu perusahaan. Pentingnya laporan keuangan juga diungkapkan bahwa laporan keuangan merupakan sarana untuk mempertanggungjawabkan apa yang dilakukan oleh manajer atas sumber daya pemilik. Salah satu parameter penting dalam laporan keuangan yang digunakan untuk mengukur kinerja manajer adalah laba. Pelaporan keuangan bertujuan untuk mengkomunikasikan informasi akuntansi dalam membantu pengguna untuk membuat keputusan bisnis yang relevan bagi perusahaan untuk mempertahankan serta meningkatkan kembali posisi keuangan dan kinerjanya. Hal tersebut menggambarkan bahwa informasi yang menggambarkan keuangan dan keadaan ekonomi yang memmengaruhi perusahaan disajikan dalam laporan keuangan, dimana pihak manajemen memiliki hak prerogatif mengungkapkan data dalam laporan keuangan tersebut. Kemahiran dan pengetahuan manajer dalam bisnis berfungsi sebagai kunci bahwa laporan keuangan yang disajikan handal dan akan membantu para pengguna laporan dalam pengambilan keputusan (Banderlipe II, 2009).

Menurut Statement of Financial Accounting Concept (SFAC) No. 1, informasi laba merupakan perhatian utama untuk menaksir kinerja atau pertanggungjawaban manajemen. Selain itu, informasi laba juga membantu pemilik atau pihak lain dalam menaksir earnings power perusahaan di masa yang akan 
ISSN: 2302-8556

E-Jurnal Akuntansi Universitas Udayana

Vol.22.1. Januari (2018): 1-29

datang. Salah satu cara manajer menggunakan hak prerogatifnya berkaitan dengan penyusunan laporan keuangan perusahaan yang menggunakan dasar akrual.Selain itu, adanya pemanfaatan celah dalam penggunaan dasar akrual oleh pihak manajemen disaat penyusunan laporan keuangan sehingga manajer dapat mengatur laba dengan cara menaikkan, menurunkan, atau meratakan laba dikenal dengan istilah manajemen laba (earnings management).

Pengungkapan laba perusahaan tentu akan mempengaruhi nilai perusahaan dan keputusan para pemangku kepentingan (stakeholders). Namun, dalam beberapa kasus, laporan tersebut telah disalahgunakan dan menjadi bencana yang mengejutkan seluruh dunia bisnis. Enron, WorldCom, Tyco, dan bahkan ditutupnya Kantor Akuntan Publik (KAP) Arthur Andersen adalah beberapa bentuk kegagalan yang terjadi dikarenakan penilaian manajer yang menyesatkan para pengguna mengenai laba perusahaan yang dilaporkan (Pergola, 2005).

Salah satu contoh kasus manajemen laba pada perusahaan jasa yang ada di Indonesia yaitu kasus PT. Kereta Api Indonesia (PT. KAI). Kasus PT. KAI terdeteksi adanya kecurangan dalam penyajian laporan keuangan. Ini merupakan suatu bentuk penipuan yang dapat menyesatkan investor dan stakeholder lainnya. Diduga terjadi manipulasi data dalam laporan keuangan PT. KAI tahun 2005, dimana perusahaan tersebut dicatat meraih keutungan sebesar Rp. 6,9 Miliar. Padahal apabila diteliti dan dikaji lebih rinci, perusahaan seharusnya menderita kerugian sebesar Rp. 63 Miliar. Kerugian ini terjadi karena PT. KAI telah tiga tahun tidak dapat menagih pajak pihak 
ketiga. Tetapi, dalam laporan keuangan itu, pajak pihak ketiga dinyatakan sebagai pendapatan. Padahal, berdasarkan Standar Akuntansi Keuangan, tidak dapat dikelompokkan dalam bentuk pendapatan atau asset. Dalam hal ini seharusnya auditor yang melakukan penugasan audit mengetahui adanya kekeliruan dalam pencatatan transaksi atau perubahan keuangan tersebut. Maka dari itu, Menteri Keuangan (Menkeu) terhitung sejak tanggal 6 juli 2007, membekukan izin Akuntan Publik Drs. Salam Mannan, pemimpin rekan pada Kantor Akuntan Publik (KAP) S. Mannan, Sofwan, Adnan dan Rekan selama 10 bulan melalu keputusan Menkeu nomor 500/KM.1/2007. Sanksi pembekuan izin diberikan karena AP tersebut telah melakukan pelanggaran terhadap Standar Profesional Akuntan Publik (SPAP) dan Kode Etik dalam kasus audit umum atas laporan keuangan PT. KAI tahun 2005 (Rizkia, 2012).

Perusahaan tersebut merupakan contoh atau sebagian kecil dari perusahaan yang melakukan kecurangan pada pelaporan keuangan, karena pada tahun-tahun sebelumnya pernah pula terjadi kasus serupa pada perusahaan-perusahaan besar lainnya. Mungkin banyak perusahaan lain yang melakukan praktek serupa, tetap tidak atau belum terdeteksi. Kecurangan dalam laporan keuangan yang dilakukan oleh manajemen, terutama kecurangan dalam bentuk penyajian laporan keuangan tidak lagi secara objektif memberikan informasi apa yang telah dilakukan dan dialami perusahaan. Manajemen laba dapat dimanfaatkan oleh manajer untuk melakukan kecurangan dalam laporan keuangan dimana manajemen mengambil kebijakan 
ISSN: 2302-8556

E-Jurnal Akuntansi Universitas Udayana

Vol.22.1. Januari (2018): 1-29

dengan melakukan rekayasa dan merencanakan kecurangan-kecurangan yang akan dilakukannya dengan sengaja.

Manajemen laba merupakan sebuah fenomena yang sampai saat ini masih diperdebatkan mengenai pemahaman etis dan tanggung jawab sosialnya. Manajemen laba berada di grey area antara sebuah kecurangan dan merupakan aktivitas yang diijinkan oleh prinsip akuntansi. Hal ini dikarenakan terdapat perbedaan pendapat mengenai tanggung jawab sosial dan pemahaman etis diantara setiap orang. Berdasarkan hal tersebut, laporan keuangan dapat disebut sebagai tanggung jawab sosial pribadi dan cerminan perilaku etis dari orang yang membuat laporan keuangan tersebut (Sri Sulistyanto, 2008:110).

Fischer dan Rosenzweigh (1995) mengatakan bahwa banyak manajer menganggap praktik manajemen laba adalah tindakan yang wajar dan etis serta merupakan alat sah manajer dalam melakukan tanggung jawabnya untuk mendapatkan keuntungan atau return perusahaan. Sedangkan Merchant dan Rockness (1994) menyatakan bahwa manajemen laba yang banyak dilakukan selama ini merupakan perbuatan yang legal, dengan artian tidak bertentangan dengan standar akuntansi yang berlaku. Berdasarkan pendapat tersebut manjemen laba merupakan sebuah tindakan etis dan wajar yang dilakukan oleh manajemen perusahaan.

Pihak manajemen melakukan hal tersebut mungkin didasari keinginan untuk memenuhi tujuan pribadi mereka sendiri dan/atau untuk memanfaatkan insentif tersebut terkait dengan penggunaan dasar akrual dalam penyusunan laporan keuangan 
(Ball dan Shivakumar, 2006).Manajemen merupakan pihak yang dikontrak oleh pemegang saham untuk bekerja demi kepentingan pemegang saham. Manajemen diberikan sebagian kekuasaan untuk membuat keputusan bagi kepentingan terbaik pemegang saham. Oleh karena itu, manajemen wajib mempertanggungjawabkan semua upayanya kepada pemegang saham.

Pemikiran bahwa pihak manajemen dapat melakukan tindakan yang hanya memberikan keuntungan bagi dirinya sendiri didasarkan pada suatu asumsi yang menyatakan setiap orang mempunyai perilaku yang mementingkan diri sendiri atau self-interested behaviour. Keinginan, motivasi dan utilitas yang tidak sama antara manajer dan pemegang saham menimbulkan kemungkinan manajer bertindak merugikan pemegang saham, antara lain berperilaku tidak etis dan cenderung melakukan kecurangan akuntansi. Para manajer melakukan manajemen laba merupakan usaha manajer (agent) untuk melindungi kepentingannya yang berbeda dengan kepentingan investor dan kreditur (principal). Agent yang bertindak rasional akan berusaha memaksimumkan kepentingannya yang seringkali dilakukan dengan mengorbankan kepentingan principal. Hal ini dilakukan dengan cara mengelola atau memanipulasi laporan labarugi perusahaan.

Menurut (Copeland, 1968), manajemen laba adalah suatu tindakan memaksimumkan atau meminimumkan laba untuk tujuan tertentu. Perilaku manajemen laba selalu diasosiasikan dengan perilaku yang negatif karena manajemen 
ISSN: 2302-8556

E-Jurnal Akuntansi Universitas Udayana

Vol.22.1. Januari (2018): 1-29

laba menyebabkan tampilan informasi keuangan tidak mencerminkan keadaan yang sebenarnya (Putra, 2009).

Manajemen perusahaan melaksanakan praktik manajemen laba dengan melakukan manipulasi laporan keuangan dan memanfaatkan kebijakan-kebijakan akuntansi. Manajer cenderung memanipulasi laba dengan mengendalikan transaksi akrual, yaitu transaksi yang tidak berpengaruh terhadap aliran kas (Friedlan, 1994). Akuntansi akrual terdiri atas non discretionary accruals (NDA) dan discretionary accruals (DA). NDA merupakan akrual yang ditentukan berdasarkan kondisi ekonomi. Sedangkan DA merupakan akrual yang telah ditentukan oleh pihak manajemen. Manajer memilih kebijakan dalam hal estimasi akuntansi dan metode akuntansi (Xiong, 2006).

Selain itu perilaku manipulasi ini juga terjadi karena adanya asimetri informasi yang tinggi antara manajemen dan pihak yang tidak mempunyai sumber, dorongan, akses yang memadai terhadap informasi untuk memonitor tindakan manajer. Manajemen laba (earning manajement) dapat diukur dengan discretionary accruals karena dapat mendeteksi manajemen laba dengan baik Dechow, dkk. (1995).

Agency theory memaparkan bahwa adanya pemisahan antara kepemilikan dan pengelolaan perusahaan yang dapat menimbulkan konflik. Terjadinya konflik yang disebut agency conflict atau agency problem, disebabkan pihak-pihak yang terkait yaitu principal (yang memberi kontrak atau pemegang saham) dan agent 
(yang menerima kontrak dan mengelola dana principal) mempunyai kepentingan yang saling bertentangan. Jika agent dan principal berupaya memaksimalkan utilitasnya masing-masing, serta memiliki keinginan dan motivasi yang berbeda, maka ada alasan untuk percaya bahwa agent (manajemen) tidak selalu bertindak sesuai keinginan principal Jensen dan Meckling, (1976). Pada satu sisi, agent memiliki informasi yang lebih banyak dibanding principal, di sisi lain karena manajemen yang mengelola perusahaan secara langsung, hal ini menimbulkan adanya ketidakseimbangan informasi (information asymmetry).

Sri (2008) dalam Adriyani (2011) menyatakan bahwa asimetri informasi adalah kesenjangan informasi antara manajer dan pihak luar peusahaan (pemilik, calon investor, kreditur, supplier, regulator, pemerintah, dan stakeholder lain) yang mempunyai keterbatasan sumber dan akses untuk memeroleh informasi mengenai perusahaan. Kesenjangan informasi inilah yang mendorong manajer untuk berperilaku oportunis dalam mengungkapkan informasi-informasi penting mengenai perusahaan.

Keberadaan asimetri informasi menyebabkan manajer menjadi pihak yang lebih banyak mengetahui informasi mengenai perusahaan dibandingkan pihak lain (investor). Sehingga hal inilah yang menyebabkan manajer mempunyai kesempatan untuk melakukan manajemen laba. Terlihat bahwa asimetri informasi dengan manajemen laba berhubungan positif, yang berarti semakin besar asimetri informasi maka semakin besar dorongan bagi manajer untuk melakukan manajemen laba. 
ISSN: 2302-8556

E-Jurnal Akuntansi Universitas Udayana

Vol.22.1. Januari (2018): 1-29

Ada banyak cara yang dilakukan manajer untuk memengaruhi laporan keuangan. Pertama, dengan cara memilih metode dan standar akuntansi. Kedua, dengan mengendalikan berbagai akrual yang membuat komponen akrual perusahaan menjadi lebih besar dibandingkan komponen kasnya (Sulistyanto, 2008). Alasan utama mengapa seorang manajer perusahaan mengelola dan mengatur laba padahal aktivitas ini cenderung melanggar peraturan yaitu seorang manajer mengelola laba untuk menciptakan kesejahteraan bagi pemilik atau pemegang saham perusahaan yang dikelolanya maupun untuk memaksimalkan keuntungan bagi dirinya sendiri, dalam hal ini pengelolaan laba bersifat oportunistik (Sulistyanto, 2008).

Secara teoritis, pihak manajemen yang memiliki persentase yang tinggi dalam kepemilikan saham akan bertindak layaknya seseorang yang memegang kepentingan dalam perusahaan. Asumsi ini sejalan dengan teori berbasis kontrak (contracting-based theory) yang menunjukkan bahwa manajemen akan efisien dalam memilih metode akuntansi yang akan memberikan nilai tambah bagi perusahaan (Christie dan Zimmerman, 1994). Manajer yang memegang saham perusahaan akan ditinjau oleh pihak-pihak yang terkait dalam kontrak seperti pemilihan komite audit yang menciptakan permintaan untuk pelaporan keuangan berkualitas oleh pemegang saham, kreditur, dan pengguna laporan keuangan untuk memastikan efisiensi kontrak yang dibuat dibuat. Dengan demikian, manajemen akan termotivasi untuk mempersiapkan laporan keuangan yang berkualitas. Hal ini akan mencerminkan kondisi kontrak yang lebih baik (Ball et al., 2000, 2003). Oleh karena itu, 
kemungkinan bahwa tingkat kepemilikan manajerial akan berada di arah yang sama untuk menekan pemanfaatan akrual diskresioner (manajemen laba) oleh pihak manajemen.

Kehadiran motivasi dan peluang merupakan insentif bagi manajer untuk mengelola laba. Menurut Positif accounting theory yang dikembangkan oleh (Watts dan Zimmerman, 1986), motivasi manajemen laba meliputi bonus plan, debt covenant, dan politic cost. Manajer termotivasi mengelola laba untuk mencapai target kinerja dan kompensasi bonus, meminimalkan kemungkinan pelanggaran perjanjian utang, dan meminimalkan biaya politik karena intervensi pemerintah dan parlemen. Beberapa peneliti telah meneliti tentang pengaruh political cost, debt covenant, dan bonus plan terhadap manajemen laba, namun dari hasil penelitian tersebut masih terdapat ketidak konsistenan hasil.

Manajemen laba dapat dipengaruhi oleh berbagai macam faktor, salah satu yang dapat memengaruhinya adalah ukuran perusahaan. Ukuran perusahaan adalah tingkat identifikasi kecil atau besarnya perusahaan. Menurut Hilmi dan Ali (2008) ukuran perusahaan dapat ditentukan berdasarkan jumlah tenaga kerja, kapitalisasi pasar, total penjualan, total nilai aktiva, dan sebagainya. Semakin besar kapitalisasi pasar menandakan semakin perusahaan diketahui oleh masyarakat, semakin besar penjualan menandakan perputaran uang semakin banyak, dan semakin besar aktiva menandakan modal yang ditanam semakin banyak. Penelitian ini menggunakan total aset sebagai proksi ukuran perusahaan. Pemilihan total aset dikarenakan total aset 
ISSN: 2302-8556

E-Jurnal Akuntansi Universitas Udayana

Vol.22.1. Januari (2018): 1-29

relatif lebih stabil daripada ukuran lain untuk menilai ukuran perusahaan (Sudarmadji dan Sularto, 2007).

(Muliati, 2011) serta (Jao dan Pagalung, 2011) menemukan bahwa ukuran perusahaan dengan manajemen laba berpengaruh negatif. Perusahaan besar kurang memiliki motivasi dalam melakukan praktik manajemen laba. Hal ini dikarenakan pemegang saham dan pihak luar di perusahaan besar dianggap lebih kritis dibandingkan dengan perusahaan kecil. Namun, Rahmani dan Mir (2013) menemukan bahwa ukuran perusahaan dan manajemen laba berpengaruh positif. Perusahaan besar mempunyai dorongan yang cukup besar untuk melaksanakan praktik manipulasi laba, alasan utamanya karena perusahaan yang berukuran besar harus dapat memenuhi ekspektasi yang tinggi dari pemegang saham atau investornya.

Political cost sering diproksikan dengan ukuran perusahaan Anggraini dan Trisnawati (2008) Semakin besar ukuran perusahaan, maka semakin besar pula kemungkinan perusahaan tersebut memilih metode akuntansi yang menurunkan laba. Pengambilan langkah tersebut dikarenakan dengan laba yang tinggi pemerintah akan segera mengambil tindakan, misalnya dengan mengenakan peraturan antitrust, menaikan pajak pendapatan perusahaan, dan lain-lain (Saputra dkk 2003). Perusahan besar mempunyai insentif yang cukup besar untuk melakukan manajemen laba, karena salah satu alasan utamanya adalah perusahaan besar harus mampu memenuhi ekspektasi dari investor atau pemegang sahamnya. Sedangkan beberapa peneliti 
seperti (Guna dan Herawaty, 2010), (Sosiawan, 2012) menyatakan bahwa ukuran perusahaan tidak berpengaruh terhadap manajemen laba.

Debt covenant menyatakan bahwa manajer termotivasi melakukan manajemen laba untuk menghindari pelanggaran perjanjian utang. Kreditor biasanya membatasi pembayaran dividen, pembelian kembali saham beredar, dan penambahan utang untuk menjamin pembayaran pokok utang dan bunga (Watts \& Zimmerman 1986). Achmad dkk (2007) Menggunakan rasio total hutang terhadap total aset untuk mengukur tingkat debt covenant. Penelitian tersebut menyatakan bahwa motivasi debt covenant dan motivasi biaya politik berpengaruh positif terhadap manajemen laba sedangkan Amijaya dan Prastiwi (2013) menemukan pengaruh yang berbeda.

Kontrak hutang merupakan salah satu motivasi manajer untuk melakukan manajemen laba. Manajer perusahaan yang melakukan pelanggaran perjanjian hutang cenderung memilih metode akuntansi yang memiliki dampak meningkatkan laba (Sweeney: 1994) dalam Achmad et al (2007). Hal ini untuk menjaga reputasi mereka dalam pandangan pihak eksternal. Perusahaan yang mempunyai resiko debt to equity cukup tinggi, maka akan mendorong manajer perusahaan untuk cenderung menggunakan metode akuntansi yang dapat meningkatkan pendapatan atau laba. Perusahaan dengan rasio debt to equity yang tinggi akan berakibat menimbulkan kesulitan dalam memeroleh dana tambahan dari pihak kreditor dan bahkan perusahaan dapat terancam melanggar perjanjian hutang. 
ISSN: 2302-8556

E-Jurnal Akuntansi Universitas Udayana

Vol.22.1. Januari (2018): 1-29

Leverage finansial (hutang dibagi total aktiva) adalah pengukur bagi kontrak antara manajer dengan pemberi modal (Christie, 1990) yang dapat dijelaskan dengan debt covenant hypothesis dalam teori akuntansi positif (Watts \& Zimmerman, 1986). Leverage finansial menggambarkan hubungan antara total assets dengan modal saham biasa atau menunjukkan penggunaan hutang untuk meningkatkan laba (Wild, Bernstein, \& Subramanyam, 2001). Sedangkan rasio leveragemenunjukkan seberapa besar asset didanai dengan hutang sehingga menunjukkan resiko bagi pemberi pinjaman. Leverage penting untuk dianalisis karena berkaitan dengan kinerja perusahaan (Weill, 2000). Midiastuty dan Mahfoedz (2003) dimana hubungannya menyatakan bahwa kepemilikan manajerial dengan manajemen laba berhubungan negatif. Penelitian Ujiyantho dan Pramuka (2007) menyatakan bahwa kepemilikan manajerial berpengaruh negatif signifikan terhadap manajemen. Jadi semakin besar saham yang dimiliki oleh manajer dimungkinkan tindakan manajer yang melakukan manajemen laba akan berkurang karena manajer merasa ikut mempunyai perusahaan. Berdasarkan uraian di atas, maka hipotesis penelitian ini adalah.

$\mathrm{H}_{1}$ : Kepemilikan manajerial berpengaruh negatif terhadap manajemen laba.

Dalam penelitian Herawati dan Baridwan (2007) ditemukan bahwa periode saat pelanggaran terjadi, manajemen perusahaan yang melanggar tidak termotivasi untuk mengurangi pelanggaran utang atau bahkan mengeliminasi pelanggaran perjanjian yang telah terjadi. DeFond dan Jiambalvo (1994) dalam Herawaty (2007) juga tidak menemukan manipulasi positif pada tahun pelanggaran dan malah 
menemukan manipulasi negatif yang terjadi. Berdasarkan uraian di atas, maka hipotesis penelitian ini adalah:

$\mathrm{H}_{2}$ : Kebijakan hutang berpengaruh negatif terhadap manajamen laba

Muliati (2011) serta Nariastiti dan Dwi Ratnadi (2014) menemukan bahwa ukuran perusahaan dengan manajemen laba berpengaruh negatif. Perusahaan besar kurang memiliki motivasi dalam melakukan praktik manajemen laba. Hal ini dikarenakan pemegang saham dan pihak-pihak yang berkepentingan di perusahaan besar dianggap lebih kritis dibandingkan dengan perusahaan kecil. Basis investor yang lebih besar terdapat pada perusahaan besar, sehingga perusahaan besar mendapat pressure yang lebih kuat untuk bisa menampilkan laporan keuangan yang dapat dipercaya (Marihot dan Setyawan, 2007). Berdasarkan uraian di atas, maka hipotesis penelitian ini adalah:

$\mathrm{H}_{3}$ : Ukuran perusahaan berpengaruh negatif terhadap manajemen laba.

\section{METODE PENELITIAN}

Desain penelitian yang digunakan didalam penelitian ini adalah penelitian dengan metode kuantiatif yang berbentuk asosiatif. Dimana penelitian kuantitatif adalah penelitian yang menggunakan angka-angka ataupun tabel-tabel didalam menganalisanya dengan model matematis. Pengertian metode asosiatif adalah penelitian yang menyatakan hubungan antara dua variable atau lebih (Sugiyono, 2013:55). Penelitian ini dilakukan di Bursa Efek Indonesia yaitu Perusahaa Jasa non keuangan yang bergerak di bidang Restoran, Hotel dan Pariwisata, Advertising 
ISSN: 2302-8556

E-Jurnal Akuntansi Universitas Udayana

Vol.22.1. Januari (2018): 1-29

Printing dan Media, dan Jasa Komputer dan Perangkatnya pada tahun 2012 - 2015 yang berjumlah 32 perusahaan yang dimuat dalam IDX tahun 2012 - 2015. Obyek Penelitian adalah suatu sifat dari obyek yang ditetapkan oleh peneliti untuk dipelajari dan kemudian memperoleh kesimpulan (sugiyono, 2013:38). Obyek dalam penelitian ini adalah Perusahaan jasa non keuangan. Menurut (Sugiyono, 2015:39), Variebel dependen atau terikat (Y) adalah suatu variable yang dipengaruhi atau menjadi akibat, arena adanya variable bebas. Dalam penelitian ini yang menjadi variable terikat adalah Manajemen Laba.

Menutu (Sugiyono, 2015:39), Variabel independen atau variabel bebas (X) adalah suatu variabel yang memengaruhi atau menjadi sebab perubahanya atau timbulnya variabel dependen (variabel terikat), variabel bebas dalam penelitian ini adalahKepemilikan manajerial $\left(\mathrm{X}_{1}\right)$, Kebijakan utang $\left(\mathrm{X}_{2}\right)$, dan Ukuran perusahaan $\left(\mathrm{X}_{3}\right)$.

Berdasarkan jenis data yang digunakan dalan penelitian ini adalah Data kuantitatif merupakan data yang berupa angka-angka (Sugiyono, 2015:137). Data kuantitatif dalam penelitian ini adalah laporan keuangan dari perusahaan jasa non keuangan yang terdaftar du Bursa Efek Indonesia tahun 2012-2015.

Berdasarkan sumbernya, data yang digunakan dalam penelitian ini adalah data sekunder yaitu didapat secara tidak langsung dari obyek penelitian, misalnya melalui dokumen atau orang lain (Sugiyono, 2012). Data sekunder yang digunakan dalam penelitian ini berupa laporan keuangan tahunan dan data kepemilikan saham, 
kebijakan hutang dan ukuran perusahaan yang di peroleh dari bursa Efek Indonesia (BEI) yang diakses melalui www.idx.co.id dan Indonesia Captal Market Directory (ICMD).

Data dalam penelitian ini adalah data sekunder yang didapatkan dari Bursa Efek Indonesia. Populasi dalam penelitian ini adalah perusahaan jasa non keuangan yang terdaftar dan telah melakukan pelaporan keuangannya di Bursa Efek Indonesia (BEI) periode tahun 2012-2015.Dalam Penelitian ini, teknik pengambilan sampel yang digunakan yaitu purposive sampling.

Metode pengumpulan data yang digunakan dalam penelitian ini adalah metode observasi non partisipan, yaitu teknik pengumpulan data observasi atau pengamatan dimana peneliti tidak telibat secara langsung dan hanya sebagai pengaman independen (Sugiyono, 2012). Data yang digunakan berasal dari dokumen-dokumen yang sudah tersedia dengan cara mengunduh laporan keuangan tahunan (Annual report) pada perusahaan jasa non keuangan yang terdaftar di Bursa Efek Indonesia (BEI) dari tahun 2012-2015 yang diperoleh dari www.idx.co.id yang merupakan website/situs resmi Bursa Efek Indonesia (BEI).

Regresi linear berganda dalam penelitian ini digunakan untuk mengetahui atau memperoleh gambaran mengenai pengaruh variabel bebas terhadap variabel terikat dengan bantuan Software Statistical Package for Social Science (SPSS) for Windows. Model regresi linear berganda ini dirumuskan sebagai berikut:

$$
\mathrm{DAC}_{\mathrm{t}}=\beta_{\mathrm{o}}+\beta_{1} \mathrm{MGR}_{\mathrm{t}}+\beta_{2} \mathrm{DER}_{\mathrm{t}}+\beta_{3} \operatorname{LnSIZE}_{\mathrm{t}}+\mathrm{e}_{\mathrm{t}}
$$


Keterangan:

$\mathrm{DAC}_{\mathrm{t}}$ : nilai discretionary accruals yang dihitung menggunakan model jones yangdimodifikasi oleh Dechow et al pada tahun t.

MGR $_{t}$ : kebijakan Managerial, yang diukur dengan jumlah presentase saham yang dimiliki oleh manajer.

DER $_{\mathrm{t}} \quad$ : kebijakan hutang, yang diukur dengan membandingkan jumlah utang terhadap ekuitas

SIZE $_{t}$ : ukuran perusahaan, yang diukur dari jumlah total asset perusahaan.

єt : error

\section{HASIL DAN PEMBAHASAN}

Statistik deskriptif dalam penelitian ini disajikan untuk memberikan informasi mengenai karakteristik variabel-variabel penelitian, antara lain minimum, maksimum, mean, dan standar deviasi. Pengukuran rata-rata (mean) merupakan cara yang paling umum digunakan untuk mengukur nilai sentral dari suatu distribusi data. Sedangkan, standar deviasi merupakan perbedaan nilai data yang diteliti dengan nilai rataratanya. Hasil statistik deskriptif dapat dilihat pada Tabel 1 yaitu sebagai berikut.

Tabel 1.

\section{Hasil Statistik Deskriptif}

\begin{tabular}{lrrrrr}
\hline & N & Minimum & Maximum & \multicolumn{1}{c}{ Mean } & Std. Deviation \\
\hline & 67 &, 02 & 70,72 & 13,8400 & 16,35330 \\
Kebijakan utang & 67 &, 10 & 3,23 &, 7787 &, 70569 \\
Ukuran perusahaan & 67 & 14,37 & 28,88 & 24,2734 & 3,64032 \\
Manajemen laba & 67 &, 01 &, 85 &, 3127 &, 19728 \\
Valid N (listwise) & 67 & & & & \\
\hline
\end{tabular}

Sumber: data sekunder diolah, (2017)

Berdasarkan tabel di atas dapat dilihat nilai minimum untuk kepemilikan manajerial adalah 0,02 dan nilai maksimumnya adalah 70,72. Mean untuk kepemilikan manajerial adalah 13,84, hal ini berarti rata-rata nilai kepemilikan 
manajerial sebesar 13,84. Standar deviasinya 16,35, hal ini berarti terjadi penyimpangan nilai kepemilikan manajerial terhadap nilai rata-ratanya yaitu sebesar 16,35 .

Variabel kebijakan hutang nilai minimumnya adalah 0,10 dan nilai maksimumnya adalah 3,23. Mean variabel kebijakan hutang adalah 0,77 , hal ini berarti bahwa rata-rata nilai kebijakan hutang sebesar 0,77. Standar deviasinya sebesar 0,79 , hal ini berarti terjadi penyimpangan nilai kebijakan hutang terhadap nilai rata-ratanya sebesar 0,70 .

Variabel ukuran perusahaan nilai minimumnya adalah 14,37 dan nilai maksimumnya adalah 28,88. Mean variabel ukuran perusahaan adalah 24,27, hal ini berarti rata-rata ukuran perusahaan sebesar 24,27. Standar deviasinya sebesar 3,64, hal ini berarti terjadi penyimpangan nilai ukuran perusahaan terhadap nilai rataratanya sebesar 3,64.

Variabel manajemen laba nilai minimumnya adalah 0,01 dan nilai maksimumnya adalah 0,85. Mean variabel nilai manajemen laba adalah 0,31, hal ini berarti rata-rata manajemen laba sebesar 0,31 . Standar deviasinya sebesar 0,19 , hal ini berarti terjadi penyimpangan nilai manajemen laba terhadap nilai rata-ratanya sebesar 0,19. Analisis regresi linear berganda digunakan untuk mengetahui pengaruh antara variabel bebas terhadap variabel terikat. Dalam penelitian ini analisis regresi linear berganda digunakan untuk mengetahui besarnya pengaruh kepemilikan manajerial, kebijakan hutang, dan ukuran perusahaan terhadap manajemen laba. 
ISSN: 2302-8556

E-Jurnal Akuntansi Universitas Udayana

Vol.22.1. Januari (2018): 1-29

Tabel 2.

Analisis Regresi Linear Berganda

\begin{tabular}{|c|c|c|c|c|c|c|}
\hline \multirow[b]{2}{*}{ Model } & & \multicolumn{2}{|c|}{$\begin{array}{l}\text { Unstandardized } \\
\text { Coefficients }\end{array}$} & \multirow{2}{*}{$\begin{array}{c}\begin{array}{c}\text { Standardize } \\
\text { Coefficients }\end{array} \\
\text { Beta } \\
\end{array}$} & \multirow[b]{2}{*}{$\mathbf{t}$} & \multirow[b]{2}{*}{ Sig. } \\
\hline & & B & Std. Erro & & & \\
\hline \multirow[t]{4}{*}{1} & (Constant) & ,507 & ,161 & & 3,156 &, 002 \\
\hline & Kepemilikan manajerial &,- 004 & 001 &,- 030 & $-2,430$ & 018 \\
\hline & Kebijakan hutang &,- 019 & 003 &,- 067 & $-5,659$ & 001 \\
\hline & Ukuran perusahaan &,- 022 & 004 &,- 098 & $-5,868$ & 000 \\
\hline
\end{tabular}

Nilai konstanta sebesar 0,507 artinya jika variabel kepemilikan manajerial, kebijakan hutang dan ukuran perusahaan dianggap konstan (tetap atau tidak ada perubahan), maka managemen laba sebesar 0,507. Nilai koefisien $b_{1}$ sebesar $-0,004$ artinya jika nilai variabel kepemilikan manajerial meningkat sebesar satu satuan maka managemen laba menurun sebesar 0,004 dengan asumsi variabel kepemilikan manajerial, kebijakan hutang dan ukuran perusahaan tetap konstan.

Nilai koefisien $b_{2}$ sebesar $-0,019$ artinya jika kebijakan hutang meningkat sebesar satu satuan maka managemen laba meurun sebesar 0,019 dengan asumsi variabel kepemilikan manajerial, ukuran perusahaan tetap konstan.

Nilai koefisien $b_{3}$ sebesar -0,022 artinya jika ukuran perusahaan meningkat sebesar satu satuan maka managemen laba turun sebesar 0,022 dengan asumsi variabel variabel kepemilikan manajerial, kebijakan hutang tetap konstan. 
Uji koefisien determinasi dilakukan untuk mengetahui seberapa jauh kemampuan variabel bebas (independen) menerangkan variabel terikatnya (dependen), ini dapat dilihat dari nilai $\mathrm{R}^{2}$ yaitu adjusted $\mathrm{R}^{2}$.

\section{Tabel 3.}

\section{Nilai Koefisien Determinasi ( $\left.\mathbf{U j i} \mathbf{R}^{2}\right)$}

\begin{tabular}{lrrrrr}
\hline Model & $\mathbf{R}$ & R Square & $\begin{array}{r}\text { Adjusted } \\
\text { R Square }\end{array}$ & $\begin{array}{r}\text { Std. Error of } \\
\text { the Estimate }\end{array}$ & $\begin{array}{c}\text { Durbin- } \\
\text { Watson }\end{array}$ \\
\hline 1 &, $557^{\text {a }}$ &, 310 &, 306 &, 18863 & 1,870 \\
\hline Sumber: & data sekunder diolah, $(2017)$ & & &
\end{tabular}

Berdasarkan Tabel 5 nilaiadjustedR ${ }^{2}$ sebesar 0,306 , ini berarti sebesar 30,6 persen variabel kepemilikan manajerial, kebijakan hutang, dan ukuran perusahaan, mempengaruhi managemen laba sedangkan sisanya sebesar 69,4 persen dipengaruhi oleh variabel lain yang tidak dimasukan dalam penelitian.

Uji kelayakan model (uji F) bertujuan untuk menguji apakah semua variabel bebas berpengaruh terhadap variabel terikat dan untuk mengetahui model regresi yang digunakan dalam penelitian ini layak uji atau tidak. 
ISSN: 2302-8556

E-Jurnal Akuntansi Universitas Udayana

Vol.22.1. Januari (2018): 1-29

\section{Tabel 4.}

Uji

Kelayakan Model (Uji F)

\begin{tabular}{llrrrrr}
\hline Model & & $\begin{array}{c}\text { Sum of } \\
\text { Squares }\end{array}$ & df & Mean Square & F & Sig. \\
\hline 1 & Regression &, 327 & 3 &, 109 & 3,064 &, $034^{\mathrm{a}}$ \\
& Residual & 2,242 & 63 &, 036 & & \\
& Total & 2,569 & 66 & & & \\
\hline
\end{tabular}

Sumber: data sekunder diolah, (2017)

Berdasarkan Tabel 4 diperoleh nilai dari signifikansi 0,003 yang lebih kecil dari 0,05. Ini berarti bahwa ada pengaruh antara variabel kepemilikan manajerial, kebijakan hutang dan ukuran perusaha secara simultan terhadap variabel manajemen laba. Sehingga dapat dikatakan bahwa model adalah layak (fit).

Uji hipotesis dilakukan untuk mengetahui apakah variabel independen secara parsial mempunyai pengaruh terhadap variabel dependen. Hasil pengujian hipotesis (uji t) dapat dilihat pada tabel 5 berikut.

Tabel 5.

\section{Uji Hipotesis (Uji t)}

\begin{tabular}{|c|c|c|c|c|c|c|}
\hline \multirow{2}{*}{\multicolumn{2}{|c|}{ Model }} & \multicolumn{2}{|c|}{$\begin{array}{l}\text { Unstandardized } \\
\text { Coefficients }\end{array}$} & \multirow{2}{*}{$\begin{array}{c}\text { Standardized } \\
\text { Coefficients } \\
\text { Beta } \\
\end{array}$} & \multirow[b]{2}{*}{$\mathbf{t}$} & \multirow[b]{2}{*}{ Sig. } \\
\hline & & B & Std. Error & & & \\
\hline \multirow[t]{4}{*}{1} & (Constant) & ,507 &, 161 & & 3,156 & ,002 \\
\hline & Kepemilikan manajerial &,- 004 & 001 &,- 030 & $-2,430$ & ,018 \\
\hline & Kebijakan hutang &,- 019 &, 003 &,- 067 & $-5,659$ & 001 \\
\hline & Ukuran perusahaan &,- 022 & ,004 &,- 098 & $-5,868$ & ,000 \\
\hline
\end{tabular}

Sumber: data sekunder diolah, (2017) 
Berdasarkan Tabel 18 diketahui bahwa nilai T hitung sebesar -2,430 dengan sig 0,018 yang berarti Ho ditolak atau kepemilikan manajerial berpengaruh negatif dan signifikan terhadap manajemen laba.

Berdasarkan Tabel 18 diketahui bahwa nilai T hitung sebesar -5,659 dengan sig 0,001 yang berarti Ho ditolak atau kebijakan hutang berpengaruh negatif terhadap manajemen laba.

Berdasarkan Tabel 4.8 diketahui bahwa nilai T hitung sebesar -5,868 dengan sig 0,038 yang berarti Ho ditolak atau Ukuran perusahaan berpengaruh positif dan signifikan pada kepemilikan manajerial.

Hasil pengujian secara empirik membuktikan bahwa kepemilikan manajerial berpengaruh negatif dan signifikan terhadap manajemen laba. Hal ini berarti semakin meningkat kepemilikan manajerial akan berdampak pada penurunan manajemen laba. Kepemilikan manajerial adalah saham yang dimiliki oleh manajemen secara pribadi maupun saham yang dimiliki oleh anak cabang perusahaan yang bersangkutan beserta afiliasinya (Herawaty, 2008). Investor institusional dan manajemen memiliki insentif yang kuat untuk mendapatkan informasi prapengungkapan (predisclosure information) mengenai perusahaan untuk memenuhi tanggungjawab fidusiarinya serta untuk meningkatkan kinerja portofolio mereka (Darmawati, 2003 dalam Kartikasai, 2011). Shleifer dan Vishny (1986) menyatakan bahwa kepemilikan saham yang besar dari segi nilai ekonomisnya memiliki insentif untuk memonitor. Secara teoritis ketika kepemilikan manajemen rendah, maka insentif terhadap kemungkinan 
ISSN: 2302-8556

E-Jurnal Akuntansi Universitas Udayana

Vol.22.1. Januari (2018): 1-29

terjadinya perilaku oportunistik manajer akan meningkat. Kepemilikan manajemen terhadap saham perusahaan dipandang dapat menyelaraskan potensi perbedaan kepentingan antara pemegang saham luar dengan manajemen (Jansen dan Meckling, 1976). Sehingga permasalahan keagenen diasumsikan akan hilang apabila seorang manajer adalah juga sekaligus sebagai seorang pemilik.

Menurut teori akuntansi, manajemen laba ditentukan oleh motivasi manajer perusahaan. Motivasi yang berbeda akan menghasilkan manajemen laba yang berbeda pula, seperti manajer yang memiliki saham di perusahaan dan manajer yang tidak memiliki saham di perusahaan. Hal ini sesuai dengan kriteria pengelolaan perusahaan yang dibedakan menjadi dua kriteria: (1) perusahaan dipimpin oleh manajer dan pemilik (owner-manager) dan (2) perusahaan yang dipimpin oleh manajer dan bukan pemilik (non owners-manager). Dua kriteria ini dapat mempengaruhi manajemen laba, sebab kepemilikan saham oleh manajer akan ikut menentukan kebijakan dan pengambilan keputusan terhadap metode akuntansi yang akan diterapkan pada perusahaan yang mereka kelola (Boediono, 2005). Pendapat tersebut sesuai dengan Midiastuty dan Mahfoedz (2003) dimana hubungannya menyatakan bahwa kepemilikan manajerial dengan manajemen laba berhubungan negatif. Penelitian Ujiyantho dan Pramuka (2007) menyatakan bahwa kepemilikan manajerial berpengaruh negatif signifikan terhadap manajemen. Jadi semakin besar saham yang dimiliki oleh manajer dimungkinkan tindakan manajer yang melakukan manajemen laba akan berkurang karena manajer merasa ikut mempunyai perusahaan. 
Hasil pengujian secara empirik membuktikan bahwa kebijakan hutang berpengaruh negatif terhadap manajemen laba. Hal ini berarti semakin tinggi kebijakan hutang maka semakin menurun menajemen laba. Motivasi debt covenant (perjanjian hutang) disebabkan oleh munculnya perjanjian kontrak antara manajemen dan perusahaan yang berbasis kompensasi manajerial (Astuti, 2005). Motivasi ini muncul karena perjanjian antara manajemen dan pemilik perusahaan berbasis pada kompensasi manajerial dan perjanjian hutang (Ujiyantho, 2007). Belkaoui (dalam Ujiyantho, 2007) menjelaskan semakin tinggi rasio hutang suatu perusahaan maka semakin dekat perusahaan tersebut dengan kendala-kendala dalam perjanjian hutang dan semakin besar probabilitas pelanggaran perjanjian, jadi semakin kecil manajer menggunakan metode-metode akuntansi yang meningkatkan income. Disebutkan dalam hipotesis perjanjian hutang bahwa manajer akan membuat pilihan akuntansi untuk mengurangi kemungkinan perusahaan mereka akan melanggar perjanjian hutang.

Manajemen perusahaan yang melanggar berupaya menghindari konsekuensi pelanggarannya yang cenderung dapat memberikan beban yang berat bagi perusahaan dan bagi manajer perusahaan tersebut. Perusahaan menghindari berbagai penalti keuangan, seperti kemungkinan percepatan jatuh tempo hutang, peningkatan tingkat suku bunga, negosiasi ulang masa hutang. Manajemen perusahaan bersikap oportunis dan tidak menyukai resiko sehingga berusaha untuk mementingkan kepentingannya sendiri dan menghindari resiko yang ada. Oleh karena itu, manajemen perusahaan 
ISSN: 2302-8556

E-Jurnal Akuntansi Universitas Udayana

Vol.22.1. Januari (2018): 1-29

yang melanggar perjanjian hutang termotivasi untuk melakukan manajemen laba melalui discretionary accruals yang meningkatkan laba sebelum terjadi pelanggaran hutang. Dalam penelitian Herawati dan Baridwan (2007) ditemukan bahwa periode saat pelanggaran terjadi, manajemen perusahaan yang melanggar tidak termotivasi untuk mengurangi pelanggaran hutang atau bahkan mengeliminasi pelanggaran perjanjian yang telah terjadi. DeFond dan Jiambalvo (1994) dalam Herawaty (2007) juga tidak menemukan manipulasi positif pada tahun pelanggaran dan malah menemukan manipulasi negatif yang terjadi.

Hasil pengujian secara empirik membuktikan bahwa ukuran perusahaan berpengaruh negatif terhadap manajem laba. Hal ini menunjukkan bahwa semakin besar ukuran perusahaan akan menurunkan manajamen laba. Ukuran perusahaan dapat dinyatakan dalam total aktiva, penjualan dan kapitalisasi pasar. Ketiga pengukuran tersebut seringkali digunakan untuk mengidentifikasi ukuran suatu perusahaan karena semakin besar aktiva yang dimiliki oleh perusahaan, maka semakin besar pula perputaran uang di perusahaan tersebut, dan semakin besar kapitalisasi pasar maka perusahaan tersebut semakin dikenal oleh masyarakat. Perusahaan yang besar lebih diperhatikan oleh masyarakat sehingga mereka akan lebih berhati-hati dalam melakukan pelaporan keuangan, sehingga akan berdampak perusahaan tersebut melaporkan kondisinya lebih akurat. Peasnell, Pope, dan Young (1998) menunjukkan adanya hubungan negatif antara ukuran perusahaan dan manajemen laba di Inggris. Dengan ini disimpulkan bahwa manajer yang memimpin 
perusahaan yang lebih besar memiliki kesempatan yang lebih kecil dalam memanipulasi laba dibandingkan dengan manajer di perusahaan kecil. Penelitian Chtourou, Bedard, dan Courteau (2001) menemukan bahwa ukuran perusahaan di Amerika Serikat berpengaruh negatif terhadap manajemen laba pada semua kelompok pengujian. Perusahaan yang lebih besar berkesempatan lebih kecil dalam melakukan manajemen laba dibandingkan perusahaan kecil

Muliati (2011) serta Nariastiti dan Dwi Ratnadi (2014) menemukan bahwa ukuran perusahaan dengan manajemen laba berpengaruh negatif. Perusahaan besar kurang memiliki motivasi dalam melakukan praktik manajemen laba. Hal ini dikarenakan pemegang saham dan pihak-pihak yang berkepentingan di perusahaan besar dianggap lebih kritis dibandingkan dengan perusahaan kecil. Basis investor yang lebih besar terdapat pada perusahaan besar, sehingga perusahaan besar mendapat pressure yang lebih kuat untuk bisa menampilkan laporan keuangan yang dapat dipercaya (Marihot dan Setyawan, 2007).

\section{SIMPULAN}

Berdasarkan hasil analisis data dan pembahasan pada bab sebelumnya, maka dapat ditarik simpulan bahwa Kepemilikan manajerial berpengaruh negatif dan signifikan terhadap manajemen laba. Kebijakan utang berpengaruh negatif dan signifikan terhadap manajemen laba. Ukuran perusahaan berpengaruh negatif dan signifikan terhadap manajemen laba. 
ISSN: 2302-8556

E-Jurnal Akuntansi Universitas Udayana

Vol.22.1. Januari (2018): 1-29

Berdasarkan hasil penelitian dan kesimpulan yang diperoleh dalam penelitian ini, maka saran yang dapat diberikan adalahBagi perusahaan,Penelitianini menggambarkan bahwa kepemilikan manajerial membantu dalam proses meminimalisasi adanya praktik manajemen laba. Perusahaan dapat meningkatkan kepemilikan manajerial agar kinerja pihak manajemen meningkat seiring dengan harapan mereka dalam mencapai keuntungan yang maksimal. Begitu juga dengan kebijakan utang dan ukuran perusahaan. Semakin tinggi rasio utang suatu perusahaan maka semakin dekat perusahaan tersebut dengan kendala-kendala dalam perjanjian utang dan semakin besar probabilitas pelanggaran perjanjian, jadi semakin kecil manajer menggunakan metode-metode akuntansi yang meningkatkan income. Ukuran perusahaan juga merupakan hal penting karna semakin besar perusahaan tersebut kemungkinan terjadinya manajemen laba itu sangat kecil. Hal ini dikarenakan semakin besar ukuran suatu perusahaan, maka akan semaikn tinggi pula permintaan informasi perusahaan oleh publik.

\section{REFERENSI}

Achmad, Komarudin, Imam Subekti, dan Sari Atmini, 2007. Investigasi Motivasi dan Strategi Manajemen Laba pada Perusahaan Publik di Indonesia. Simposium Nasional Akuntansi X. Ikatan AkuntanIndonesia. Makassar.

Amijaya, Muhammad Dody dan Andri Prastiwi. 2013. "Pengaruh Kualitas Audit terhadap Manajemen Laba”. Diponegoro Journal of Accounting Vol. 2 No. 3.

Andriyani, Aulia Mufti. 2011. "Pengaruh Lingkungan Sekolah dan Minat Belajar Siswa terhadap Prestasi Belajar Ekonomi Siswa Kelas VIII MTs I'Anah Futuhiyah Bodeh Pemalang Tahun Ajaran 2010/2011”. (Skripsi SarjanaS1). Surakarta: Universitas Muhammadiyah Surakarta. 
Anggraini, Fivi dan Ira Trisnawati. 2008. Pengaruh Earnings Management Terhadap Konservatisma Akuntansi. Jurnal Bisnis dan Akuntansi Vol. 10 No. 1 Tahun 2008 Halaman 2-36.

Ball, R., dan Shivakumar, L. 2005. "Earnings Quality In UK Private Firms: Comparative Loss Recognition Timeliness". Journal of Accounting and Economics, Vol. 39: 83-128.

Banderlipe, M. R. (2009). "The Impact of Selected Corporate Governance Variables in Mitigating Earnings Management in The Philippines," DLSUBusiness \& Economics Review, 19(1), 17-27.

Belkaoui, Ahmed Riahi. 2007. TeoriAkuntansi, Edisi lima,Jakarta:Salemba Empat, halaman 182-205.

Belkoui dan Ahmed Riahi. 2000. Accounting theory, $4^{\text {th }}$ Edition, Thomson Learning

Boediono, G. 2005. "Kualitas Laba : Studi Pengaruh Mekanisme Corporate Governance dan Dampak Manajemen Laba dengan Menggunakan Analisis Jalur.” Simposium Nasional Akuntansi VII, Solo,15-16 September 2005

Christie, Andrew A. dan Jerold L. Zimmerman. 1994. Efficient and Opportunistic Choices of Accounting Procedures : Corporate Control Contests. The Accounting Review, Vol. 69, No. 4, October, 539-556.

Copeland,R.M.1968."Income Smoothing, Journal of Accounting Research", Empirical Reseacrh in Accounting, Selected studies 6 (Supplement).

Dechow, P. M., \& Skinner, D. J. 2000. Earnings management: Reconciling the views of accounting academics, practitioners, and regulators. Accounting Horizons, $14(2), 235-250$

DeFond dan Jiambalvo (1994). Pengaruh manajemen laba dan kepemilikan manajerial pada kesejahteraan pemegang saham perusahaan akuisisi.

Ghozali, Imam. 2011. Aplikasi Analisis Multivariate dengan Program SPSS. Badan Penerbit Universitas Diponegoro. Semarang. Governance dan Dampak Manajemen Laba dengan Menggunakan Analisis Jalur”. Simposium Nasional Akuntansi VIII. September: 1-23.

Guna, Welvin, I, dan Herawaty Harleen, 2010. Pengaruh Mekanisme Good Corporate Governance, Indepedensi Auditor, Kualitas Audit, dan Faktor Lainnya Terhadap Manajemen Laba. Jurnal Bisnis dan Akuntansi, Vol. 12, No.1, Hal 5368. 
ISSN: 2302-8556

E-Jurnal Akuntansi Universitas Udayana

Vol.22.1. Januari (2018): 1-29

Herawati, Nurul \& Zaki Baridwan. 2007. Manajemen Laba Pada Perusahaan Yang Melanggar Perjanjian Utang. Simposium Nasional Akuntansi X. Ikatan Akuntan Indonesia. Makasar..

Jensen, Michael C. and William H. Meckling. 1976. "Theory of the Firm: Managerial Behavior, Agency Costs and Ownership Structure". Journal of Financial Economics, Vol. 3, No. 4, hal. 305-360.

Midiastuty, P., Machfoedz, M., 2003. Analisis Hubungan Mekanisme Corporate Governance dan Indikasi Manajemen laba. Simposium Nasional Akuntansi VI.,

Peasnell, K.V., P. V. Pope and S. Young. 2000. "Detecting Earnings Management Using Cross Sectional Abnormal Accruals Model". Accounting and Business Research, Vol. 30, No. 4: 313-326

Sosiawan, Santhi Yuliana. 2012. Pengaruh Kompensasi, Leverage, Ukuran Perusahaan, Earning Power terhadap Manajemen Laba. JRAK Vol. 8, No. 1, Februari.

Sugiyono. 2013. Metode Penelitian Bisnis (Pendekatan Kuantitatif, Kualitatif dan $R \& D)$. Bandung: ALFABETA.

Sulistyanto, Sri. 2008. Manajemen Laba: Teori dan Model Empiris. Jakarta: Grasindo.

Sweeney, A.P. 1994. Debt Covenant Violations and Managers Accounting Responses. Journal of Accounting and Economics 1.

Ujiyantho, Muh. Arief \& Bambang Agus Pramuka. 2007. Mekanisme Corporate Governance, dan Kinerja Keuangan (Studi Pada Perusahaan Go Public Sektor Manufaktur), Artikel Ilmiah dalam Simposium Nasional Akuntansi X, Makassar.

Watts, Ross L dan Zimmerman, Jerold L. (1990). Positive Accounting Theory: A Ten Year Perspective.The Accounting Review. Vol. 65. No.1. pp.131 156

Wild, John J., K. R. Subramanyam, dan Robert F. Halsey. 2004. Financial Statement Analysis.The McGraw-Hill Companies Inc., diterjemahkan oleh Yanivi S. Bachtiar dan S. Nurwahyu Harahap. 2005. Analisis Laporan Keuangan. Jakarta: Salemba Empat 